\title{
Comparative study of expandable cage with integrated plate versus non expandable cage in cervical spine corpectomies
}

\author{
Nakul Pahwa', Suniti Kumar Saha², Kaushik Roy ${ }^{3}$, Debajyoti Pathak, \\ Shuvayu Bandyopadhyay ${ }^{5}$ \\ ${ }_{1,4,5}$ Post Doctoral Trainee, Department of Neurosurgery, Nil Ratan Sircar Medical College and Hospital, Kolkata, \\ West Bengal, ${ }^{2}$ Professor and Head, Department of Neurosurgery, Nil Ratan Sircar Medical College and Hospital, \\ Kolkata, West Bengal, ${ }^{3}$ Professor, Department of Neurosurgery, Nil Ratan Sircar Medical College and Hospital, \\ Kolkata, West Bengal
}

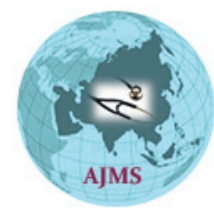

\section{A B S T R A C T}

Background: The use of expandable cages in cervical spine has gained popularity over the last decade. They have been used in dorsal spine since long but were rarely used in cervical spine due to their high cost. Now, with more insight into their mechanics, many advantages have been noted over the fixed cages along with similar efficacy and with no added complications. Aims and Objectives: To study the benefits of expandable cage with incorporated anterior cervical plate over non expandable cage in cervical spine corpectomies. Materials and Methods: Ten cases of two level corpectomy were operated in each group and compared for intraoperative time, postoperative fusion rates and complications. Results: Intraoperative time was less in the expandable cage group. Fusion rates were comparable at 6 month follow up. No reported long term complication in both groups. Conclusion: Expandable cages are less frequently used in cervical spine due to their significantly higher cost but there are advantages such as decreased intraoperative manipulation and operative time, less damage to end plates and also useful in cases of poor bone quality.
http://nepjol.info/index.php/AJMS DOI: 10.3126/ajms.v11i2.26515 E-ISSN: 2091-0576 P-ISSN: 2467-9100

Key words: Expandable cage; Cervical spine; Corpectomy; Fusion rate

\section{INTRODUCTION}

With the advent of anterior cervical spine surgery after its original description by Smith and Robertson and Cloward over 50 years ago, the possibility of treatment solutions for the cervical spine has immensely expanded ${ }^{1}$. Cervical spine corpectomy is usually done for decompression of anterior spinein cervical spondylosis, traumatic injuries to spine, kyphotic deformities and ossified posterior longitudinal ligament. It forms part of radical surgery for cervical spondylosis and requires subsequent reconstruction by means of graft and instrumented fusion.

Two of the commonly used methods are reconstruction using non expandable cage and expandable cage with integrated cervical plate, the second one being the less commonly used in cervical spine mainly due to it's high cost. Expandable cages have been used in dorsal spine since long ${ }^{2}$ and they are now gaining popularity among neurosurgeons for their varied advantages. The aim of current study was to assess the benefits of expandable cage over non expandable in terms of operative time, fusion rates and postoperative complications.

\section{MATERIALS AND METHODS}

This was a prospective study done in our institute over a period of one year. Twenty patients were included in the study who were operated for cervical corpectomy and reconstruction. In 10 patients reconstruction was done 
using expandable cage with integrated cervical plate and in the other group non expandable cage was used.

\section{Inclusion criteria}

- All patients with traumatic and degenerative cervical spondylosis

- Only those who underwent two level corpectomy.

\section{Exclusion criteria}

- All other spondylotic pathologies

- Patients with OPLL

- Patients above 60 years.

All patients had a postoperative drain which was removed on the second postoperative day. The two groups were compared for the intraoperative manipulation and intraoperative time, immediate and long term complications and fusion rates at 6 months follow up.

\section{RESULTS}

Following were the results of our study.

\section{Intraoperative manipulation}

In the non-expandable group, most of the cases required adjustment of the cage by trimming the ends and impacting the cage with hammer which lead to more end plate damage. One case required cage removal and re-insertion. These problems were not encountered in the expandable cage group as the cage was inserted in non-expanded state and then expanded to fit the space, also this lead to less end plate damage.

\section{Intraoperative time}

The average intraoperative time was 100 minutes in the non-expandable cage group while it was 90 minutes in the expandable cage group. This extra time was due to the cage adjustments required in the non-expandable group and also the more time in $\mathrm{C}$-arm adjustments due to more number of exposures required in this group.

\section{Complications}

One patient had seroma formation in the expandable cage group. Transient complications such as dysphagia in the immediate post-operative period was seen in both the groups. No major long term complications were present in both the groups.

Fusion rate

Flexion and extension dynamic X-rays done at 6 months follow up showed comparable fusion rates in both the groups.

\begin{tabular}{lccc}
\hline & $\begin{array}{c}\text { Total } \\
\text { patients } \\
\text { (n) }\end{array}$ & $\begin{array}{c}\text { Patients with } \\
\text { fusion at 6 } \\
\text { month follow up }\end{array}$ & Percentage \\
\hline $\begin{array}{l}\text { Non-expandable } \\
\text { group }\end{array}$ & 10 & 10 & 100 \\
$\begin{array}{l}\text { Expandable } \\
\text { group }\end{array}$ & 10 & 9 & 90 \\
\hline
\end{tabular}

One patient with non-fusion had severely degenerated spine with Vitamin D3 deficiency.

There have been other prospective studies on the use of expandable cage with integrated plate. The following table gives an account of the same.

The following image shows the cage employed in our study.
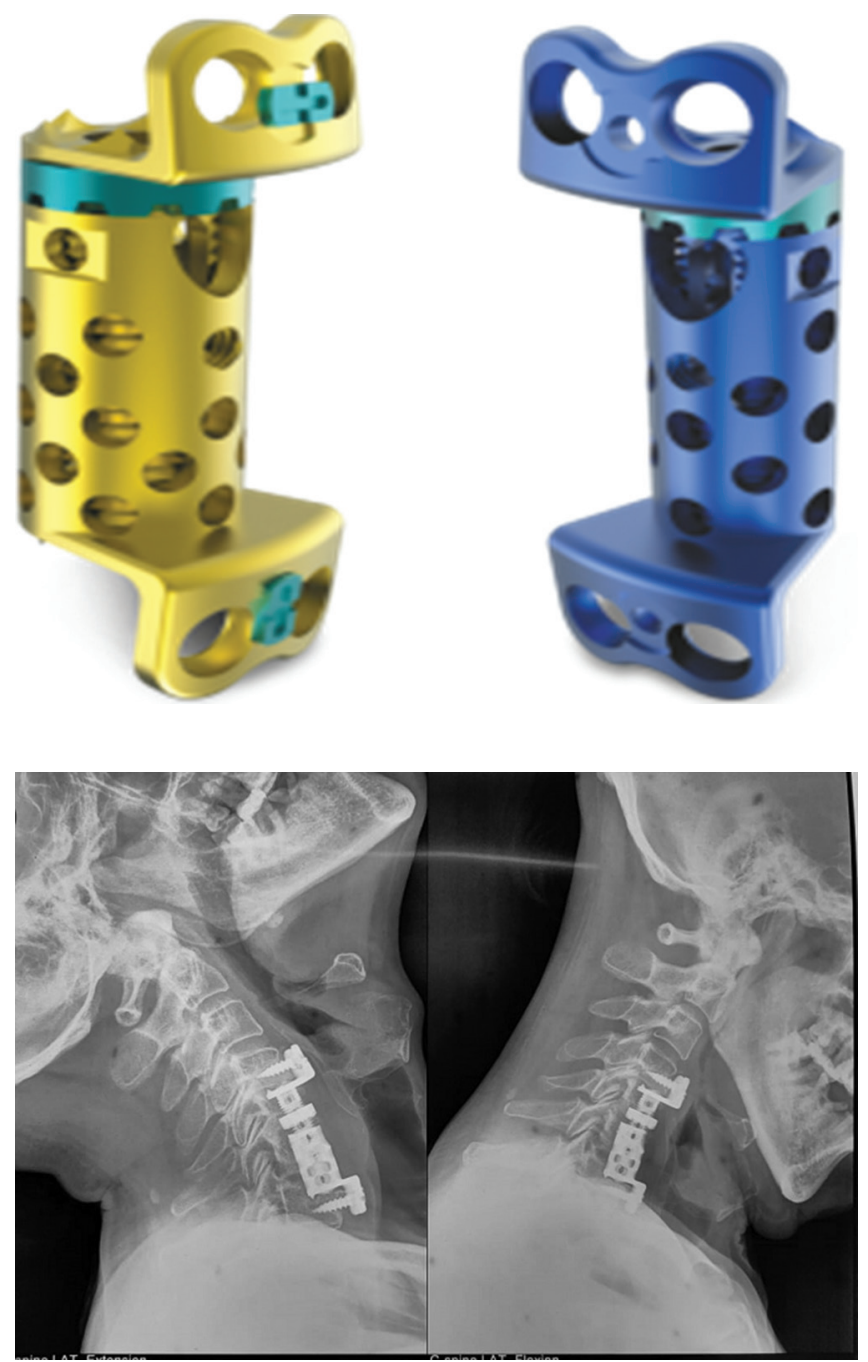

\section{DISCUSSION}

Expandable cages have not yet gained as much popularity in cervical spine as it has in the thoracic spine. This largely 


\begin{tabular}{|c|c|c|c|c|c|c|c|}
\hline Study & $\begin{array}{l}\text { Total } \\
\text { number of } \\
\text { cases }\end{array}$ & Indications & $\begin{array}{l}\text { Number of } \\
\text { levels fixed }\end{array}$ & Implants used & $\begin{array}{l}\text { Follow up } \\
\text { period }\end{array}$ & $\begin{array}{l}\text { Fusion } \\
\text { rates }\end{array}$ & Adverse events \\
\hline $\begin{array}{l}\text { Payer } \\
\text { et al }\end{array}$ & 20 & $\begin{array}{l}\text { Degenerative } \\
\text { spondylosis, } \\
\text { tumors, fractures }\end{array}$ & $\begin{array}{l}\text { One (13), } \\
\text { two(3) and } \\
\text { three(4) levels }\end{array}$ & $\begin{array}{l}\text { ADD with anterior } \\
\text { plate only(13), } \\
\text { anterior plate with } \\
\text { supplemental } \\
\text { posterior } \\
\text { fixation(5) } \\
\text { or posterior } \\
\text { supplemental } \\
\text { fixation alone (2) }\end{array}$ & 14 months & $95 \%$ & $\begin{array}{l}\text { One patient } \\
\text { with subsidence } \\
\text { requiring } \\
\text { revision }\end{array}$ \\
\hline $\begin{array}{l}\text { Arts and } \\
\text { peul }\end{array}$ & 41 & $\begin{array}{l}\text { Tumor (22), } \\
\text { degenerative } \\
\text { spondylosis } \\
\text { (20), fracture(3), } \\
\text { deformity(14), } \\
\text { infection(1) }\end{array}$ & $\begin{array}{l}\text { One or two } \\
\text { levels }\end{array}$ & $\begin{array}{l}\text { TPS, ADD Plus, } \\
\text { ADD with anterior } \\
\text { plate }\end{array}$ & 9 months & $93 \%$ & $\begin{array}{l}43 \% \\
\text { subsidence, } \\
\text { transient c5 } \\
\text { palsy due to } \\
\text { over distraction }\end{array}$ \\
\hline
\end{tabular}

is due to its high cost, which is also its main disadvantage. But there are several advantages which make expandable cages useful. One is less manipulation required as they can be inserted in non-expanded state and then expanded. This also causes less damage to end plates which is helpful in the long term. The operative time is reduced because of less manipulation and less $\mathrm{C}$-arm exposure.

In comparison with the non expandable cages, expandable cages have no difference in range of motion or stiffness although range of motion is limited compared to when only graft without fixation is used.

Another advantage that has been noted with the use of expandable cages is improvement in cervical lordosis. This has been reported to be in the range of 4-22 degrees but no study has yet been done to compare this parameter between expandable and fixed groups ${ }^{3}$.

There have been temporary complications such as dysphagia reported but no major long term complications reported. Few incidences of neurological problems have been reported due to over distraction such as C5 palsy $y^{4,5}$ but none in our study till 6 months. There were concerns regarding adjacent segment vertebral body fractures initially when expandable cages came into use but this also has not been reported barring a few cases. So they have comparable safety to fixed cages.

Fusion rates in different studies done till date including this have been comparable to fixed cages despite the earlier concerns regarding less contact area and less space to incorporate bone within the cage. Thus, considering the pros and cons expandable cages are here to stay in the treatment of cervical spondylosis.

\section{REFERENCES}

1. Yonenobu K, Fuji T, Ono $\mathrm{K}$, Okada $\mathrm{K}$, Yamamoto $\mathrm{T}$ and Harada N. Choice of surgical treatment for multisegmental cervical spondylotic myelopathy. Spine (Phila Pa 1976) 1985; 10:710-716.

2. Eleraky MA, Duong HT, Esp E and Kim KD. Expandable versus nonexpandable cages for thoracolumbar burst fracture. World Neurosurg 2011; 75(1):149-154.

3. Elder BD, Lo SF, Kosztowski TA, Goodwin CR, Lina IA, Locke JE, et al. A systematic review of the use of expandable cages in the cervical spine. Neurosurgical Review 2016; 39(1); 1-11.

4. Sakaura H, Hosono N, Mukai $Y$, Ishii T and Yoshikawa H. C5 palsy after decompression surgery for cervical myelopathy: Review of the literature. Spine 2003; 28:2447-2451.

5. Arts MP and Peul WC. Vertebral Body Replacement Systems with Expandable Cages in the Treatment of Various Spinal Pathologies: A Prospectively Followed Case Series of 60 Patients. Neurosurgery 2008; 63(3): 537-545.

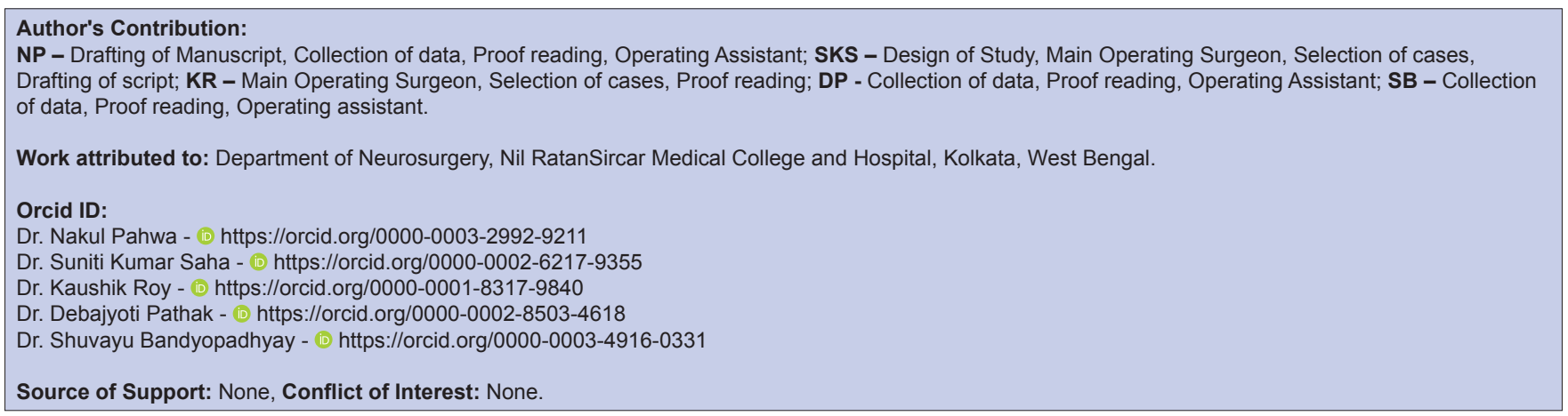

